\title{
Interventions for Physical Activity Promotion: Where is Brazil?
}

Alex Antonio Florindo ${ }^{1,2}$; Paulo Henrique Guerra ${ }^{1,3}$

In 2011, Hallal and Florindo argued that the evaluation of interventions to increase physical activity would be an important field within physical activity epidemiology in the following years ${ }^{1}$.

Their argument turned out to be true. In the global context, we had a massive increase in studies on interventions in the last ten years. While writing this editorial, we searched PubMed and Web of Science, looking for systematic reviews with the words "intervention" and "physical activity" in their titles. We found $325 \mathrm{pu}-$ blications, the first of which was published in $1978^{2}$. However, most reviews were published after 2011 (274 publications, 84.3\%), with a gradual increase from 2011 to 2016 (from 29 to 63 publications per year).

However, a more recent overview showed that the majority of the interventions had medium or small effect sizes in population physical activity levels ${ }^{3}$. Heath et al. showed medium effect sizes of pedometer-based interventions (0.68), protocols implemented in obese populations (0.44), after-school interventions in children and adolescents (0.44), and internet-based interventions (0.44). Complementarily, this overview also showed small effect sizes of interventions based on behavioral changes (0.32), interventions delivered to older adults (0.26), workplace interventions (0.21), physical activity counselling interventions in the health care sector (0.16), self-efficacy in adults (0.16), and computer-tailored interventions (0.16). Moreover, Reis et al. identified 16 physical activity interventions considered as scalable, mainly based on community-wide programs, public education, whole-of-school programs, and primary health care systems ${ }^{4}$.

All of these studies show that "interventions based on physical activity" are a recent and emerging field in public health, and community setting, education, and primary health care are important sectors for actions. However, most types of interventions only had small effects on population physical activity levels.

In the Brazilian context, policies on physical activity promotion for the whole country started in 2008, with grants coming from the Ministry of Health to cities, aiming to develop programs in primary health care settings ${ }^{5}$. In 2011, the "Academia da Saúde" program was implemented in primary health care settings to increase and improve health promotion actions, such as physical activity and healthy eating ${ }^{6}$. Now, this program reaches more than 2,500 cities in Brazil and has the potential to cover at least one million people ${ }^{7}$.

However, in Brazil, the prevalence of important types of physical activities are low. Florindo et al. showed that the prevalence of leisure-time physical activity (at least 30 minutes per day, 5 times per week, or 20 minutes of vigorous activities at least 3 times per week) was $14.8 \%$, and of transport-related physical activity 
(at least 30 minutes per day, 5 times per week, of walking or bicycling) was $11.7 \%$ in adults ${ }^{8}$. Two temporal trend studies showed that the prevalence of these same types of physical activity did not show significant changes from 2006 to 2010 and from 2006 to $2012^{9,10}$. Leisure-time physical activity did not exceed $15 \%$, and transport-related physical activity was lower than $13 \%$ in both studies. Only the prevalence of inactivity in leisure-time (individuals who did not participate in any type of physical activity) decreased from $59.1 \%$ in 2006 to 55.6 in $2012^{9}$.

However, even with the increase in the number of physical activity and health research groups ${ }^{11}$ and published papers ${ }^{12}$, intervention studies are still few in Brazil, much due to the considerable lack of financing for their development and implementation. Why is the prevalence of leisure-time and transport-related physical activity among Brazilian adults not changing even with the physical activity promotion programs that have been implemented in the last ten years? Are we going to achieve the goals established in the National Plan to Reduce Chronic Diseases and Risk Factors? The objective of this plan is to increase the prevalence of adults practicing at least 30 minutes of moderate activities 5 days per week or 20 minutes of vigorous activities 3 days per week to $22 \%$ by $2022^{13}$.

What can we do? We would like to discuss some points to contribute with this important debate to improve physical activity interventions in Brazil. We need more joint participation of researchers, practitioners, and policy makers to evaluate and improve interventions and programs. Giles-Corti et al. recommended some strategies for projects in Active Living that we ("researchers") can adopt ${ }^{14}$ : to understand the "policy world", to establish links and research agenda with policy makers and practitioners, to work with knowledge brokers and advocates, to promote interdisciplinarity, collaborative research with different sectors and training programs for health professionals and other professionals, to apply health and economic evaluation impacts, to evaluate policy reform through natural experiment studies, and to perform research focused on community needs.

In addition to "traditional" interventions (e.g., based on behavioral changes), more longitudinal studies (cohort and natural experiments) are required to examine whether possible changes in the built environment, in policies, or the implementation of programs can change health outcomes as physical activity. Two good examples of natural experiments to verify the effects of the built environment on population physical activity were the "RESIDE study" (Residential Environments Project), in Australia ${ }^{15}$, and the "IConnect study", developed in England ${ }^{16}$. Many cities in Brazil are changing their built environment. The city of Sao Paulo, for example, had a significant increase in bike paths in the last three years (http://www.cetsp.com.br/consultas/bicicleta/mapa-de-infraestrutura-cicloviaria.aspx). In addition, the Community Guide has recently published a document recommending built environment interventions for physical activity promotion in populations (https://www.thecommunityguide.org/findings/physical-activity-built-environment-approaches).

We need to follow the good examples of studies in this field to evaluate interventions in Brazil that have already been implemented. The evaluation of the "Academia da Cidade" program as a "natural experiment" in Pernambuco state ${ }^{17}$, the program that preceded the nationwide "Academia da Saúde" program ${ }^{6}$. Simoes et al. showed that people living in cities that had implemented the program were more likely to participate in leisure-time physical activity than those living in cities without the program ${ }^{17}$. 
The use of other new perspectives and tools are also welcomed to push the field into other directions. As an example, Garcia used the systems science perspective and agent-based modeling to explore how population patterns of leisure-time physical activity may emerge from the interaction between psychological, social, and environmental aspects ${ }^{18}$. These types of analyses may help us to elucidate the dynamic relationship between different layers of influence over time and to build more effective programs and policies.

Finally, we need national physical activity promotion guidelines. In Brazil, a good example was the "Dietary Guidelines for the Brazilian Population"19. Physical activity guidelines could direct actions of researchers, policy makers, practitioners, and civil society, constituting an important policy instrument in Brazil. In our opinion, these guidelines would be built grounded on an interdisciplinary perspective, with collaborators of different sectors and with innovations for physical activity promotion, as described by Silva et al. ${ }^{20}$.

In our opinion, Brazil showed good improvement in policies and in programs for physical activity promotion in the last ten years. However, to achieve better results in the physical activity level of the Brazilian population, we ("researchers") need to improve our studies and to raise more discussion about this, especially in a time of crisis. As Giles-Corti \& King once wrote, "we need to think outside the squa$\mathrm{re}{ }^{\prime 21}$ to create opportunities for active living. The Brazilian Congress on Physical Activity and Health to be held in November 2017 will be a good moment for this.

\section{Acknowledgments}

We would like to thank Leandro Martin Totaro Garcia (PhD) for his suggestions and review; and the Brazilian National Council for Scientific and Technological Development (CNPq) (grant 306635/2016-0) for the fellowship granted to Alex Antonio Florindo.

\section{Authors' contributions}

Alex Antonio Florindo elaborated the idea and developed the text. Paulo Henrique Guerra elaborated the idea, reviewed the studies and performed the critical review of the text.

\section{References}

1. Hallal PC, Florindo AA. Um olhar para o futuro da epidemiologia da atividade física. In: Florindo AA, Hallal PC, editors. Epidemiologia da Atividade Física. São Paulo: Atheneu; 2011. p. 211.

2. Garman JF. Coronary risk factor intervention--a review of physical activity and serum lipids. Am Correct Ther J. 1978;32(6):183-9.

3. Heath GW, Parra DC, Sarmiento OL, Andersen LB, Owen N, Goenka S, et al. Evidencebased intervention in physical activity: lessons from around the world. Lancet. 2012;380(9838):272-81.

4. Reis RS, Salvo D, Ogilvie D, Lambert EV, Goenka S, Brownson RC, et al. Scaling up physical activity interventions worldwide: stepping up to larger and smarter approaches to get people moving. Lancet. 2016;388(10051):1337-48.

5. Knuth AG, Malta DC, Cruz DK, Castro AM, Fagundes J, Sardinha LM, et al. Description of the countrywide physical activity network coordinated by the Brazilian Ministry of Health: 2005-2008. J Phys Act Health. 2010;7(Suppl 2):S253-8.

6. Malta DC, Barbosa da Silva J. Policies to promote physical activity in Brazil. Lancet. 2012;380(9838):195-6.

7. Florindo AA, Reis RS, Farias Junior JC, Siqueira FV, Nakamura PM, Hallal PC, et al. Description of health promotion actions in Brazilian cities that received funds to develop "Academia da Saúde" program. Rev Bras Cineantropom Desempenho Hum. 2016;18(4):483-92. 
8. Florindo AA, Hallal PC, Moura EC, Malta DC. Practice of physical activities and associated factors in adults, Brazil, 2006. Rev Saúde Públ. 2009;43(Suppl 2):65-73.

9. Mielke GI, Hallal PC, Malta DC, Lee IM. Time trends of physical activity and television viewing time in Brazil: 2006-2012. Int J Behav Nutr Phys Act. 2014;11:101.

10. Hallal PC, Knuth AG, Reis RS, Rombaldi AJ, Malta DC, Iser BP, et al. Time trends of physical activity in Brazil (2006-2009). Rev Bras Epidemiol. 2011;14(Suppl 1):53-60.

11. Santos A, Bastos LLAG, Aparecida AA, Silva PTR, ME L. Distribuição, evolução e produção científica dos grupos de pesquisa em atividade física e saúde do Brasil. Rev Bras Ativ Fís Saúde. 2012;17(4):258-62.

12. Ramires VV, Becker LA, Sadovsky ADI, Zago AM, Bielemann RM, Guerra PH. Evolução da pesquisa epidemiológica em atividade física e comportamento sedentário no Brasil: atualização de uma revisão sistemática. Rev Bras Ativ Fís Saúde. 2014;19(5):529.

13. Ministério da Saúde do Brasil. Plano de ações estratégicas para o enfrentamento das doenças crônicas não transmissíveis (DCNT) no Brasil. 2011-2022. Secretaria de Vigilância em Saúde. Departamento de Análise de Situação de Saúde. Coordenação Geral de Doenças e Agravos Não Transmissíveis Brasília, DF. 2011.

14. Giles-Corti B, Sallis JF, Sugiyama T, Frank LD, Lowe M, Owen N. Translating active living research into policy and practice: one important pathway to chronic disease prevention. J Public Health Policy 2015;36(2):231-43.

15. Giles-Corti B, Knuiman M, Timperio A, Van Niel K, Pikora TJ, Bull FC, et al. Evaluation of the implementation of a state government community design policy aimed at increasing local walking: design issues and baseline results from RESIDE, Perth Western Australia. Prev Med. 2008;46(1):46-54.

16. Goodman A, Sahlqvist S, Ogilvie D, iConnect c. Who uses new walking and cycling infrastructure and how? Longitudinal results from the UK iConnect study. Prev Med. 2013;57(5):518-24.

17. Simoes EJ, Hallal PC, Siqueira FV, Schmaltz C, Menor D, Malta DC, et al. Effectiveness of a scaled up physical activity intervention in Brazil: A natural experiment. Prev Med. 2016. DOI http://dx.doi.org/10.1016/j.ypmed.2016.09.032.

18. Garcia LMT. Desenvolvimento de um modelo baseado em agentes para investigar a conformação e evolução de padrões populacionais de atividade física no lazer em adultos. São Paulo: Universidade de São Paulo.; 2016.

19. Ministério da Saúde do Brasil. Guia Alimentar Para a População Brasileira. Secretaria de Atenção à Saúde. Departamento de Atenção Básica. 2 Edição ed. Brasília, DF. 2014.

20. Silva KS, Garcia LM, Rabacow FM, de Rezende LF, de Sa TH. Physical activity as part of daily living: Moving beyond quantitative recommendations. Prev Med. 2017;96:160-2.

21. Giles-Corti B, King AC. Creating active environments across the life course: "thinking outside the square". Br J Sports Med. 2009;43(2):109-13. 